\title{
Oscar Romero (1917-1980): A model of pastoral leadership for church leaders in Africa
}

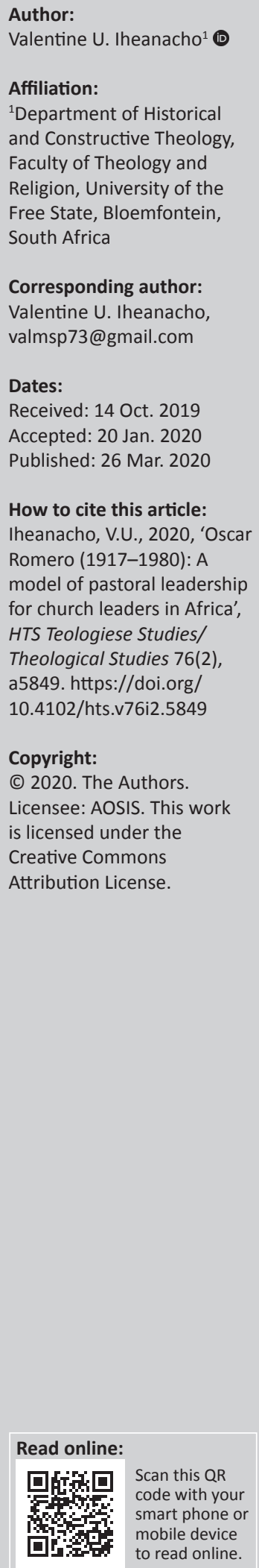

Until 1977, Monsignor Romero was a traditional Catholic bishop trained in traditional Roman theology with a penchant for order and non-involvement in 'politics'. He was also a product of the 1968 Medellin Conference which fashioned a pastoral model for the Latin American church: 'A fundamental option for the poor' on the thrust of the Second Vatican Council (1962-1965). This article seeks to present Oscar Romero within a historical context and proposes him as a servant-leader model for African church leaders, especially Catholic bishops.

Keywords: Pastor; Prophet; Shepherd; Social Justice; Peace; Liberation; Repression; Oppression.

\section{Introduction}

In his work, On the Councils and the Church, Martin Luther (1539) listed 'persecution' as one of the visible signs of the true church. For the reformer (Aland 1985):

$[T]$ he holy Christian people are externally recognized by the holy possession of the sacred cross. They must endure every misfortune and persecution, all kinds of trials and evils ... in order to become like their head, Christ. (p. 65)

In other words, it was not merely persecution for its own sake. He specified the basis for which Christians may suffer persecution: 'And the only reason they must suffer is that they steadfastly adhere to Christ and God's word, enduring this for the sake of Christ' (Aland 1985:65).

Archbishop Oscar Romero would have agreed with Luther without any hesitation (McGarry 2018):

It is important to note why [the Church] has been persecuted. Not any and every priest has been persecuted, not any and every institution has been attacked. That part of the Church has been attacked and persecuted that put itself on the side of the people and went to the people's defence. (n.p.)

However, Romero was not always the prophetic firebrand that he later became. He was not always the defender of the poor and the voice of the voiceless. His former colleagues viewed the radical conversion of Romero, from an ecclesiastical bureaucrat to an 'unrestrained' crusader of social justice and peace, as an embarrassment and a sense of betrayal. He became a thorn in the flesh of the Salvadoran powerful and ruthless oligarchy that built a feudal economy for their own benefits.

This article endeavours to narrate the story of Oscar Romero as a prophet, a shepherd, a father and a defender of the poor. He was the reluctant hero who neither aspired to, nor even desired martyrdom. Martyrdom chose Dom Romero, almost in the manner of what Leon Trotsky (cited in Akiner 2011:23) wrote about war, stating that '[y]ou may not be interested in war, but war is interested in you'.

\section{El Salvador within the context of Latin America}

From the 1960s to the early 1990s, three Central American countries, namely, Nicaragua, El Salvador and Guatemala, underwent a period of turmoil, civil wars and brutal military dictatorships. Similar to its neighbours, El Salvador - the home country of Romero - was disfigured by poverty, starvation, disease and death that permeated the lives of the common folk (Erdozaín 1981:91). It is estimated that the 12-year war, which intensified after the assassination of Romero and ended in 1992 with an armistice, must have killed roughly 75000 civilians, including the many who disappeared (Doyle \& Willard 2011). 
As elsewhere in the Americas, El Salvador has a long history of greed, injustice, cruelty and oppression. That history dates back to the time of the Spanish conquistadors in the New World after its discovery by Christopher Columbus in 1492. For instance, in a 1511 homily to a rich congregation of Europeans in Hispaniola (Dominican Republic), Fr Antonio de Montesinos (cited in KrierMich 2001) thundered as follows:

$[Y]$ ou are in mortal sin for the cruelty and tyranny you use in dealing with innocent people. By what right or justice do you keep these Indians in such cruelty and horrible servitude? (p. 240)

Sadly, this history has continued until the present day, albeit under different circumstances. The Salvadoran experience is not an isolation one. It must be squared within the larger context of Latin America.

With no Caribbean coast, El Salvador, with a population of roughly 6 million people, is the smallest country in the Americas. For most of the 20th century, the country suffered under the yoke of military tyranny and dictatorship that began in 1932. This continued uninterrupted for approximately 50 years. At the time of Romero, 14 powerful families decided the destiny of El Salvador. Altogether they owned roughly $38 \%$ of the country's arable land, leaving only about $23 \%$ of the land to the poorer $91 \%$ of the population who struggled to eke out a living through subsistence agriculture. In terms of alphabetisation, the majority of rural and urban population could not read and write (Erdozaín 1981:2-3).

In the days of Romero, El Salvador symbolised a microcosmic picture of the bigger reality of Latin America, where an extreme few were favoured to the detriment of the vast majority. Theirs was a reprehensible opulence in a sea of endemic poverty and misery. Pope Paul VI addressed that reality in his homily during the 1968 opening Mass for the meeting of the Latin American Bishops' Conference in Bogota and Medellín, Columbia. Addressing his words specifically to Latin American elites on 28 August 1968 in Bogota, the pontiff demanded ' $\mathrm{t}$ ] hat your ears and hearts be sensitive to the voices of those who ask for bread, concern, and justice' (Gremillion 1976:456). Similar to their counterparts on the rest of the continent, the Salvadoran oligarchy developed a wilful and lamentable insensitivity to the misery of the majority who were less well off. Their callous indifference only worsened with the turn of the 1970s.

In terms of church-state relationship, it is pertinent to remember that the Catholic Church in Latin America was the offspring of the wedlock between the ravaging Spanish/ Portuguese states and a 'dependent partner' church of the 16th century. According to Penny Lernoux, 'this situation has survived to modern times' (KrierMich 2001:241). It explains the visible division within the Latin American church at the time of Romero that began with the 1968 Medellín conference. That split was between a 'Church of accommodation and a Church of liberation' (KrierMich
2001:241). It also provides a background to, and an insight into the division and acrimony between the later Oscar Romero and the rest of the Salvadoran episcopacy, with the exception of Arturo Rivera y Damas.

For the purpose of history, Romero himself had previously been a pre-Vatican II traditionalist, not numbered amongst the enthusiastic progressives of the post-Vatican II and Medellín church. In a few instances, Romero had displayed his preference for the old manner of being a church. He once criticised the 22 June 1970 National Pastoral Week, organised by Archbishop Luis Chávez y González and Bishop Damas. In the judgement of Romero, then a staunch conservative, National Pastoral Week was too radical for his liking. Unlike Romero, some Salvadoran progressives viewed the Pastoral Week as 'the appearance of a new dawn for the Salvadoran church'. It did so on the basis 'of its stress on the democratisation of church structures, the formation of Christian Base Communities (CEBs) and the development of methods to combat unjust structures' (Brett 2008:720).

In a 1973 editorial for the archdiocesan newspaper, Orientacion, Romero accused the Jesuits of using Marxist literature and 'false liberating education' to mislead students. The Jesuits, through sociology classes, required their students to have a field experience by visiting poor neighbourhoods (Brett 2008:721). In 1975, as a consultant to the Pontifical Commission for Latin America, Romero showed no restraint in his condemnation of the Salvadoran church for its radicalism. For the Jesuits, his usual targets, he reserved the heaviest punch, labelling them as a 'national scandal [with their] Marxist orientation' (Brett 2008:721) and 'hate-filled Christologies' (Forché 1996:61).

Given his antecedents, it is not surprising that his former conservative friends opposed him. His complete 'turnaround' as a defender of the 'new way', which he had previously criticised, seems almost reminiscent of the 'Saul-to-Paul' episode. Although not intended, his 'turnaround' was construed as a betrayal. Consequentially, opposition to Romero became messy, on some occasions, as the counterpastorals issued by the two camps within the Salvadoran episcopal conference became vivid in 1978. As a way to bring back Romero to their fold, the other bishops placed a disclaimer on Romero and Damas because of the joint pastoral letter issued by the duo on 06 August 1978 entitled, 'The Church and the popular political organizations'. The two bishops were very critical of the Salvadoran church's lukewarm response to popular political organisations of the masses. Romero and Damas were convinced that the church had a moral obligation to support and encourage the poor in their struggle for justice. They affirmed that the peasants, through their unions, had the right to participate in the decision process of their country's economic, political and cultural developments (Brett 2008:725).

Similarly, they also maintained that the legitimate demands of the people must never be misinterpreted as acts of 
terrorism or, worse still, misconstrued as unlawful subversion. Both bishops posited that the protection of the weak was the principal purpose of laws and of social organisations' (Keogh 1981:66). No sensible person would quarrel with that position of the two bishops on the civic duties of the citizenry. Regrettably, in El Salvador of the late 1970s, such a position was almost similar to fanning the embers of political violence and repressions. It was on the occasion of such division within the Salvadoran episcopacy that Romero became all the more convinced that church unity was illusory if churchmen preferred to ignore the harsh economic and political realities of their 'flock'.

\section{Romero as a historic event}

In terms of his historical milieu, Romero belonged to the 20th century, described as a 'tyrant century' by the Russian poet Osip Mandelstam (Bergman 1996:2). It was the century that witnessed the horrors at Auschwitz and other similar atrocities, the painful memories of which led Pope Benedict XVI (2005-2013) to remark in 2006 that '[a]t AuschwitzBirkenau humanity walked through a "valley of darkness"' (Benedict XVI 2006:n.p.). That century saw more than its share of the blood of countless innocent victims and martyrs. Amongst such hapless victims, Jon Sobrino identifies Romero as 'the most universal Christian at the end of the twentieth century [since in him] that which is Christian and that which is human is very present' (Wright 2009:142).

For Romero, his attainment of stardom was helped by the fact that he was killed on his duty post as a priest and bishop. It is only at the celebration of the liturgy that a priest is most vulnerable and defenceless. His violent death at the hand of his assassin(s) elevated Romero and put him in the line of martyred bishops similar to the 11th-century Polish martyr St Stanislaus of Krakow and Thomas Beckett of Canterbury who was killed in the 12th century on his way to Vespers (McGarry 2018). Even before the formal recognition of his heroic virtues as a forthright bishop through beatification (2015) and canonisation (2018) by the Catholic Church, the 'conversion' of Romero as a gadfly for social justice was never put into question. His 'conversion' left his detractors (the nuncio included) rather startled and dumbfounded. They tried to smear him with the brush of 'Marxism' by portraying him as the leader of the Marxist clergy who had subverted the campesinos (peasants) with Marxist propaganda (Erdozaín 1981:37). Some went further to brand him a liar, an impostor who was parading himself as a bishop, a psychopath - worse than a communist (Barros 2005:363).

The story of Romero's 'conversion' from an 'impeccable' churchman to a rabble-rouser for the cause of justice and human rights has been told a thousand times, and therefore may become superfluous to merit any repetition. Suffice it to note, about his seemingly 'conversion', Romero himself preferred to call it the 'rediscovery of his roots', or 'an evolution' - that is, 'a development in the process of self-awareness' (Morozzodella Rocca 2015:80; CampbellJohnston SJ 2011:n.p.). Writing to Pope John Paul II in November 1978, Romero described his pastoral conduct as motivated by 'a special pastoral fortitude', given to him by God, which 'contrasted with my temperament and my "conservative" inclinations' (Morozzodella Rocca 2015:81).

In view of the tapestry of his life, it is possible to divide his priestly and episcopal ministries into two periods: 'the pre-1977 Romero' and 'the post-1977 Romero'. The three years (1974-1977) that Romero spent as the bishop of Santiago de Maria could be regarded as both an interlude and a bridge between the 'pre- and post-1977' periods. His Santiago-deMaria years were crucial in gradually setting him on the path of 'conversion' towards social activism and a preferential option for the poor. To a discerning eye, the facts are evident to suggest that, after the violent death of his friend Fr Rutilio Grande on 12 March 1977, Archbishop Romero was never the same again. It was like the lifeless bodies of Fr Grande and his two peasant friends in Aguilares gave birth to a new man in Romero and infused into him courage that in spite of trepidation he became determined to make his voice heard. Although Romero was shy and diffident by nature, the role forged upon his shoulders by the historic circumstances of the El Salvador of his days transformed him into a roaring lion at the pulpit.

From the moment of Rutilio's death until his own tragic death 3 years later, Romero never wavered in his commitment to the cause of the poor and the oppressed. Speaking once to Fr César Jerez (Provisional of the Jesuits in Central America) about that experience, he said, ' $[w]$ hen I looked at Rutilio lying there dead, I thought: If they killed him for doing what he did, then I too have to walk the same path' (CampbellJohnston SJ 2011:n.p.). It was a path that led to his love for the poor, which was counted for him as a 'crime'. He crossed the threshold and the Rubicon of vacillation when he decided to cancel Masses in his archdiocese to have only one Mass celebrated on Sunday, 20 March 1979, for the repose of Fr Rutilio Grande. Against all odds and protestations from Archbishop Emanuele Gerada (papal nuncio), who presumably was said to have called him 'irresponsible and imprudent' (Wright 2009:46), Romero never backed down. That was the eureka moment for the archbishop. It was an unrepeatable moment of truth that finally dawned on him. Remarkable was his homily that Sunday. The applause that reverberated from the crowd served to confirm him in his decision (Wright 2009):

This applause confirms the profound joy that my heart feels upon taking possession of the archdiocese and feeling that my own weaknesses and my own inabilities can find their complement, their strength, and their courage in a united clergy. Whoever touches one of my priests, is touching me. And they will have to deal with me! (p. 49)

If there were any residual doubts regarding the new role that the circumstances in El Salvador were thrusting upon his shoulders, such doubts evaporated as he faced the crowd of 
over 100000 people gathered outside the cathedral in response to a summons from their former vacillating archbishop. That single Mass established a direct rapport between the chief shepherd of San Salvador and his flock, and further afar in the whole of the country. It was the 'beginning of a new relationship between pastor and people that would reoccur many times during the next 3 years every time Romero preached the Sunday Mass in the cathedral' (Keogh 1981:2). Ironically, the next time a crowd of a similar magnitude that gathered again outside the same cathedral of San Salvador was exactly 3 years later, at the funeral of Monseñor Romero.

The 'crime' of the two friends was their love for the poor and their unquenchable passion for justice. And particularly for Romero, as opined by Fr Cezar Jerez: 'His crime was to love the poor, fight for social justice and speak the truth in public with fearless determination and disregard for his own personal safety' (Keogh 1981:2). His 'unique crime' positioned Romero as a historic event. It marked him out as 'one of the fearless Christian campaigners for human rights in Latin America' (Keogh 1981:1). The peculiarity of his 'crime' also made his death a historic event, unique in itself, and, in the words of the Peruvian liberation theologian Gustavo Gutiérrez, 'the death of Romero divides the recent history of the Latin American church into a before and after' (Wright 2009:3). His tragic death is the 'hermeneutic principle' to study and interpret Romero because his martyrdom was never an accident. As the logical conclusion of his 3-year prophetic ministry, his death exhibits 'the very magnitude of truth' at its very zenith! (Sobrino 1990:186).

\section{In the line of prophets}

It is now a common knowledge that the appointment of Romero to the archbishopric of the capital city was meant to be midway between the two presumed extremes represented by Bishops Damas and Alvares respectively. The former was claimed by the 'progressives' as their man, whilst the latter was regarded as ultraconservative. Romero's previous records as 'a conscientious' priest, dedicated to his 'normal' pastoral duties, did not easily endear him to many as the likely successor to Archbishop Gonzalez. With the likes of Dom Camara of Brazil and Bishop Leonidas Proaño of Ecuador, Archbishop Gonzalez, in his own way, launched his local church towards social activism. They constituted the ranks of Latin American bishops who, in discovering that their people were exploited, and by means of their pastoral activities, rediscovered their prophetic calling in service of social justice and peace for the Latin American people. They were determined, in the immediate post-Vatican II years, to confront the exploitation, injustice, underdevelopment and the frustrated hopes of their people (Galilea 1979:164-165). They were resolved to steer the church in Latin America into another direction because that church was historically conservative, defensive of the institutional church, and often allied with the oppressive oligarchy and the economic elites of the continent (Forché 1996:58).
Two years before the transfer of Romero to San Salvador, Archbishop Gonzalez, in a 1975 pastoral letter, decried the appropriation of large farmland for the plantation of coffee, cotton and sugarcane for export, whilst only a small portion of unproductive land was allocated to poor peasants. Without disregarding Romero's originality and personal charisma, it stands to reason that his social activism did not occur in a vacuum. The prophetic calling came to him as an unwilling prophet because the time of his ascending to the cathedral seat of San Salvador and his installation in 1977 coincided with one of the most turbulent moments in the history of El Salvador. It was in that difficult context that he found himself. He was prodded by necessity to provide leadership (Hodgson 1993:1). However, he did not provide the type of leadership that those who appointed him had expected: to be acceptable to the wealthy and mighty of El Salvador, to discipline 'wayward' activist priests and to restore priestly mission to feudal pastoral ministry (Hodgson 1993:60).

On the contrary, the new archbishop gradually learned 'on the job' of a different kind, with another job description as events unfolded. For instance, one incidence in June 1977 showed him as learning and trying to immerse himself into the reality of the campesinos. That incidence took place in a village where Romero had gone to visit the peasants after an attack by the National Guard. He arrived at the village on a late Sunday afternoon after a hectic morning in San Salvador, hungry and tired. He asked for food, but he was given 'a small tamale', which did not assuage his hunger. His request for more food was ignored not out of contempt but because the peasant had nothing left. It was reported that the archbishop felt sad. He later expressed his displeasure about that incidence and the lack of sufficient food in a meeting with some seminarians, nuns and lay ministers. It was explained to him that the poor campesinos had given him the food they had in their possession (Erdozaín 1981:26-27). It was one of those experiences that cemented his uncommon attachment to the poor that uniquely placed him at the helm as their friend and defender. Once Romero had established himself through his acquaintance with the poor and oppressed people of El Salvador, he found his voice and courage. He took to another level the social activism bequeathed to him by his immediate predecessor.

In his description of the legacy of Romero, Sobrino depicts him as homo doctus, who, as a learned person, taught by inspiring and inspired by teaching (Erdozaín1981:185), for prophets do not only denounce, they teach and point the direction of goodness and justice as much as they denounce evil and injustice. Operating within the limits of both spectra, Romero articulated his role thus: 'The law of my ministry is to maintain a position of autonomy of freedom and to provide direction as a pastor' (Forché 1996:69). He was very clear about that direction: 'What we are seeking is social justice, a more fraternal society, a redistribution of wealth, all the rights of the common good' (Forché 1996:69). 
As a compelling preacher, his voice reverberated through the length and breadth of the entire landscape of El Salvador and beyond. His weekly Sunday homilies in the cathedral of San Salvador became almost like roll calls, naming those who were 'missing' as well as those who had 'disappeared' in the previous week. In his detailed analysis of the Salvadoran reality, Romero exuded the commitment, dedication and altruism of the old prophets. As Keogh (1981:91) explicates, the archbishop's Sunday homilies provided a weekly reprieve for the people. The cathedral with the larger-than-life presence of the archbishop became a kind of an oasis of freedom and defiance for the troubled people to escape from their fear and servitude.

More so, as the poor increasingly became the major focus of his ministry, Romero himself listened increasingly to the Word of God with the ears and hearts of the poor. With his unusual power of clarity and simplicity in speech and writing, he taught his people and inspired them to stand in defence of their human rights and dignity. In his last pastoral letter, 'Mision de la Iglesiaen Medio de la Crisis del Pais', Romero (1979) identified and condemned what he called 'three idolatries' that held his people in bondage: the absolutisation of wealth; the absolutisation of the idea of private property - an increase of the wealth of a few at the expense of the majority; and the idolatry of political power, which was at the heart of the violent repression in the country. In the analysis of Romero, those three idolatries combined to form the root causes of economic, social and political underdevelopment that subjugated the entire nation (Keogh 1981:78). The clearest of his prophetic teachings was his homily of 08 July 1979, with a title that was quite ad rem: 'The prophet and the presence of God in the society'. Recalling the prophetic mandate that each Christian received at baptism, he sought to awaken that fire of prophetic mission in his listeners (Keogh 1981):

Brothers, this morning I would like to appeal to that prophetic vocation which you all have. And I would like to say to you, as I once said to you before: If anytime they stop the radio, ban the papers, deny us the possibility of speaking, kill all the priests and the bishop too; and they leave yourselves, a pueblo without priests, everyone of us must be a microphone of God; every one of you must be a messenger, a prophet; the Church will always exist in the world for as long as there remains one baptised person and that last baptised person who remains in the world, it is he who has before the entire world the responsibility to maintain the flag of Our Lord's truth and Divine Justice flying high. (p. 97)

It appears very plausible to assume that as the premonition of his imminent death became a daily reality, Romero intensified his preaching and messages (Brockman 2003:366). To be inserted here is his famous letter to President Jimmy Carter of the United States, dated 17 February 1980. The same could be said of his last homily on 23 March 1980, in which he called upon Salvadoran soldiers and security forces to obey the higher law in their consciences and to refrain from the senseless killing of their own people. Until the bitter end, he remained defiant in his denunciation of slow death by oppression and rapid death by repression. He did so with an eloquence that could be translated to mean 'when men spoke with the tongues of angels'. As for his cathedral, it became the heartbeat for all Salvadorans as the only place in the country where the truth could be named, the causes of violence identified and the perpetrators of violence and repression unmasked and held accountable for their heinous crimes committed with impunity (Wright 2009:2). To preach and expound the Gospel was for him a graced moment - an opportunity to root God's word in the history and reality of his people, which impressed a prophetic character to his preaching.

The prophetic pronunciations of Romero were not limited to the cathedral. He was at ease with communicating through radio and newspapers, in addition to the many letters he received on a daily basis from poor communities who often addressed him collectively because many of them could not read and write. His frequent visits to the campesinos in rural villages made him a mobile prophet. For the people beyond the shores of El Salvador, his acceptance speech for the award of an honorary doctorate from the University of Louvain on 02 February 1980 is evergreen (Wright 2009):

The political dimension of the faith is nothing other than the demands made upon it ... by the socio-political world in which it exists ... I am talking about an authentic option for the poor, of becoming incarnate in their world, of proclaiming good news to them, of giving them hope, of encouraging them to engage in a liberating praxis, of defending their cause and of sharing their fate. We see, with great clarity, that here neutrality is impossible. Either we serve the life of Salvadorans, or we are accomplices in their death. And here what is most fundamental about faith is given expression in history: either we believe in a God of life, or we serve the idols of death. (p. 118)

\section{A pastor who acted as a bridge}

There is a beautiful expression of Scott Wright that captures the pastoral ministry of Romero in the midst of his flock. Scott calls Romero a bridge between God and the poor. In that capacity, he went before God as a pastor with the cry and frustrated hope of his people and returned to his people as a prophet with God's word of consolation and hope (Wright 2009:112). The consolation that he brought was often tangible, through the sharing of the momentary joys and hopes of the poor such as officiating at weddings of the campesinos in remote areas of his diocese, the baptism, the First Holy Communion and Confirmation of their children. He was in 'a dialectical-give-and-take relationship' with his people (Erdozaín 1981:29). As their pastor, he opted for pastoral appeal over pomp and ceremony, humility and compassion over the trappings of power and status.

Because the poor held the key to the centrality of his 3-year episcopal ministry in San Salvador, he knew the poor not through books but through his concrete encounters with them in their own world. It was first-hand knowledge in which he came to feel their pains, sufferings and deprivations, assuring them of his pastoral closeness and fortitude. From their social standpoint, and the point of view of the oppressed and persecuted, Romero was emphatic in his teaching: 'To deny 
right to life of the poor is to deny God himself' (Barros 2005:361). He spared no effort to prevent the dehumanisation of his flock. In his empathy for, and solidarity with them, even to the point of vulnerability and defenceless, he was prepared to risk everything: 'As a pastor, I am obliged to give my life for those I love'. In more than one way, his tenure as archbishop was a springtime of faith and courage for the church in El Salvador, although not without controversies and divisions. From his own understanding and conviction, unity was a mere illusion if it ignored the real world in which people lived their lives and earned their daily bread.

Romero's episcopal motto, sentire cum ecclesia ('feeling with the church'), was his rudder in the period of his stewardship in San Salvador. It meant, in concrete terms, feeling the general pulse, especially from the people at the pastoral base. His use of episcopal office and authority was communal, not as an ecclesiastical autocrat. His concept of episcopal office was pre-eminently rooted in service. Keogh calls Romero's episcopal concept 'original and authentic' because of its communal and concrete expressions. It led him to listen to his people and allowed himself to be inspired by the people. This concept of the episcopal office, understood as service, also implied for Romero a theology of ministry, anchored on collegiality with his clergy and people. As a servant-leader, he favoured dialogue and transparency in the administration of his archdiocese.

In the turbulent situation of the time and with many oppositions from ecclesiastical high quarters, it became obvious to Romero that he must look elsewhere for a base, for support and understanding. Turning to his clergy and people encouraged him to weather the storm. That explains why, for instance, he consulted widely and listened to different viewpoints before deciding to have a single Mass celebrated in the archdiocese for the funeral of Fr Grande. The same could be said of his homilies that were often the products of teamwork, with whom he met to reflect and to gather relevant materials to be incorporated into his sermons. With the information sent to his office from various communities, even from rural areas, as well as from outside San Salvador, the archbishop masterfully endeavoured to articulate and accommodate their many concerns in the preparation of his weekly homilies. His preaching had and still has an impact nowadays because they issued from many collaborations. To have a glimpse of the impacts produced by Romero's homilies, one has to imagine oneself being actually present in the cathedral on Sunday, amidst the poor and the peasant who crowded to hear him speak as their shepherd (Erdozaín 1981:32-33).

It could be surmised with certainty that the people gathered to hear him because they could identify the contributions of their various communities and villages in the utterances of the archbishop who gave voice to their aspirations for a fair and better society. He once said: 'With this simple flock, it is easy to be a shepherd'. Those homilies truly give an insight into Romero's prophetic and pastoral soul. They also reflect his personal journey and transformation, together with his reading and re-reading of the Christian message of hope and liberation in the concrete and historical context of his people. They say something about the man who was acutely aware of his pastoral duty as the bishop of a troubled and harassed people (Erdozaín 1981:33). Acting in his capacity as the archbishop of San Salvador and the 'voice of the voiceless', Romero touched the hearts of the poor like no other person in Salvadoran history (Brett 2008:739).

\section{Romero in the African context}

In 2000 and 2001, The Economist published two separate editorials on Africa and its many problems. The first editorial entitled 'Hopeless Africa' was published on 11 May 2000. It ex-rayed Africa's myriad problems and challenges, with the conclusion that most of Africa's problems and challenges owed less to acts of God than to acts of man. In other words, Africa's problems were man-made. At the core of those problems and challenges were brutality, despotism and corruption, which were not exclusively African because they existed worldwide. However, according to The Economist (Leaders 2000:n.p.), 'African societies, for reasons buried in their cultures, seem especially susceptible to them'. A similar line of argument was operative in the second editorial of 22 February 2001, aptly titled 'Africa's elusive dawn'. It was written to counter the somewhat exaggerated African optimism of the early 2000s. As a follow-up to the editorial of the previous year, this one chronicled Africa's debt burden and underdevelopment, despite the continent's abundant resources. It maintained that 'most ordinary Africans are illserved by their leaders', which, sadly, has remained 'Africa's continuing tragedy' (Leaders 2000:n.p.).

In Christian parlance, the African tragedy could be described as rooted in mysterium iniquitatis (Sobrino 2008:73), collusion between African leaders and foreign predators who are responsible for the continent's ills and scars. The late Cameroonian theologian Jean Marc-Ela once accused the Catholic Church in Africa of holding to a model of the Christian faith that is not socially conscious, that asks no disturbing questions about demands of social justice and prophetic proclamation. As far as Marc-Ela was concerned, the African church seems oblivious to the material and economic needs of Africans, especially those in poor and rural communities. Its worries appear to be more of devotional Christianity with a penchant for doctrinal 'purity' and too fearful to dare (Marc-Ela 1986, 1988). Marc-Ela's indictment of the Catholic Church could be extended to other churches of the continent.

To traditional churches worried about the preservation of the status quo and saving the soul, Romero would retort: 'We must save not the soul at the hour of death but the living person in history' (Nouwen 1989:x). Those churches do not seem to preach a questioning God who disturbs and unsettles the consciences of those who steal and squander the wealth of Africa. The voice of prophecy is somewhat lacking in African Christianity, apart from some intermittent voices 
such as those of Desmond Tutu during the apartheid era in South Africa and Pius Ncube (former Archbishop of Bulawayo), who alone amongst Zimbabwean Catholic bishops stood up to Robert Mugabe, the late old tyrant of Zimbabwe. Although discredited by an orchestrated scandal meant to smear him for daring to tell Mugabe to relinquish power, history would be kind to him as a man of courage who, in the line of prophets, raised his voice of disapproval when it was dangerous and risky to do so.

As for Pentecostal churches, they are focused on the Gospel of prosperity that borders more on wishful thinking than on reality, with promises of wealth and escape from poverty with minimal work and sweat. Romero would say, to borrow from Nouwen (1989:x): 'When one knows that financial capital, political influence, and power are worthless, that is when one begins to experience faith and conversion'. African Christianity, whether in its devotional brand or the prosperity gospel variant, would have been distressing to Romero. With his demystification of episcopal pomp and pageantry, Romero has something to teach African church leaders about Christianity. He would say that the Christian religion does not have to be either otherworldly or materialistic as to entangle itself with the idolatry of wealth, denounced by Romero. Because the poor and oppressed ought to be at the centre of Christian ministry, invariably, churches in Africa ought not dissipate the social dynamism of the Christian faith nor exhaust themselves through 'acts of worship [and] sacramentalism, [centred around the] salvation of souls and liberation from sin' (Marc-Ela 1996:131, 134-135, 138).

In terms of its concreteness, Romero would argue that Christianity must be relevant to the social conditions of the poor, the marginalised and the downtrodden of society. As heir to Medellín, Romero empowered his people to participate actively in their own liberation from all that dehumanised them, especially the capitalistic system. The latter was a source of misery and death for many Salvadorans, as it is for many in contemporary Africa. It appears to be the case that churchmen in Africa easily make peace with political leaders, which conditions their proclamation. The consequence of such 'peace' is the preaching of divine resignation in the face of great human suffering, social injustice and deprivation that are rife in Africa. The church in Africa is yet to see the emergence of a courageous churchman such as Cardinal Jaime Sin (former archbishop of Manila in the Philippines). He played an instrumental role in the 1986 People Power Revolution (Epifanio de lo Santos Avenue [EDSA]) that toppled Emperor Ferdinand Marcos and his corrupt government. In 2001, the same Cardinal Sin sided with the Filipinos against President Joseph Estrada, which led to the removal of Estrada and his morally bankrupt administration.

\section{Conclusion}

On several occasions, Archbishop Romero stated that politics needs a pastoral orientation if it were not to be reduced to raw power manipulation in the hands of the mighty and powerful for their own self-interest at the detriment of the majority. As a prophet and shepherd, his burning desire was to see the transformation of his country's economic, political and social structures to serve the needs of the common people. For that very reason, he was more than prepared, although reluctantly at first, to confront the Salvadoran national security state, set up by the San Salvador-Washington axis. The national security state in El Salvador was kept in existence by the same Washington with every security apparatus at its disposal, even if it meant overriding the democratic rights and aspirations of the Salvadoran people. It was a system that did not tolerate any act of insubordination.

In relation to the Salvadoran Catholic Church at the time, the state showered it with privileges and inducements to buy its conscience and to elicit its cooperation to quieten the people. Romero met the strongest opposition from the church when he dared to 'step out of line' from the ecclesiastical position of maintaining a close alliance between the oppressive state and a subservient church. When the figure and personality of Romero is transported to a continent such as Africa, he has a great deal to teach African church leaders about simplicity, the forthrightness of a prophet and the dotting dedication of a shepherd. Regardless of skin colour and geography, human beings desire the same things: love, peace, justice and participation in the economic and social developments of their countries. They want a government that works with them, not over them, that stands by their side and does not ride over their back (Rousseau 2002:2).

The history of independent Africa is replete with predators and parasites masquerading as leaders. Like the Leviathan of David Hobbes that eats its offspring, African leaders feed fat on their own people. The continent is groaning for the emergence of its own courageous pastors and prophets to help shed light on its many challenges: underdevelopment, sit-tight leaders, corruption and even the exploitation of its gullible and vulnerable people by religious charlatans.

\section{Acknowledgements}

The author thanks the Jesuits for the use of their library in Johannesburg, South Africa. The author also thanks St Augustine College for allowing to use their library.

\section{Competing interests}

The author has declared that they have no financial or personal relationships which may have inappropriately influenced them in writing this article.

\section{Author's contributions}

V.U.I. is the sole author of this research article.

\section{Ethical considerations}

This article followed all ethical standards for a research without direct contact with human or animal subjects.

\section{Funding information}

As a post-doctoral research fellow, the author's studies are sponsored by the University of the Free State. 


\section{Data availability statement}

Data sharing is not applicable to this article as no new data were created or analysed in this study.

\section{Disclaimer}

The views and opinions expressed in this article are those of the author and do not necessarily reflect official policy or position of any affiliated agency of the author.

\section{References}

Akiner, A.A., 2011, Forgotten consequences: The impact of the Korean War on the influence of the military in Turkish politics and society, Lulu Press, Morrisville, NC.

Aland, K., 1985, A history of Christianity: From the beginnings to the threshold of the Reformation, vol. 1., Fortress Press, Philadelphia, PA

Barros, M., 2005, 'Dom Oscar Romero: Latin American Prophet', The Furrow 56(6), 358-365.

Benedict XVI, 2006, Pastoral visit of His Holiness Pope Benedict XVI in Poland: Address by the Holy Father: Visit to the Auschwitz camp, viewed 05 April 2019, from http:// w2.vatican.va/content/benedict-xvi/en/speeches/2006/may/documents/hf benxvi_spe_20060528_auschwitz-birkenau.html

Bergman, S., 1996, 'Twentieth-century martyrs: A meditation', in S. Bergman (ed.), Martyrs, Orbis Books, New York, NY.

Brett, E.T., 2008, 'Archbishop Arturo Rivera Damas and the struggle for social justice in El Salvador', The Catholic Historical Review 94(4), 717-739. https://doi.org/ 10.1353/cat.0.0161

Brockman, J.R., 2003, 'Romero, Oscar A', in B.L. Marthaler (ed.), New Catholic encyclopedia, 2nd edn., pp. 754-756, The Catholic University of America, Washington, DC

Campbell-Johnston SJ, M., 2011, Romero: 'The voice of those who had no voice', viewed 15 February 2019, from https://www.thinkingfaith.org/articles/20110323_1.htm.

Doyle, K. \& Willard, E., 2011, "Learn from History", 31st anniversary of the assassination of Archbishop Oscar Romero, viewed 21 February 2019, from https://nsarchive2 gwu.edu/NSAEBB/NSAEBB339/.

Erdozaín, P., 1981, Archbishop Romero: Martyr of Salvador, Orbis Books, New York, NY.
Forché, C., 1996, 'Seed of liberty/sign of hope', in S. Bergman (ed.), Martyrs: Contemporary writers on modern lives of faith, pp. 56-77, Orbis Books, New York, NY.

Galilea, S., 1979, 'Liberation theology and new tasks facing Christians', in R. Gibellini (ed.), Frontiers of theology in Latin America, pp. 163-183, Orbis Books, New York, NY.

Gremillion, J. (ed.), 1976, The Gospel of peace and justice: Catholic social teach since Pope John XXIII, Orbis Books, New York, NY.

Hodgson, I.B. (transl.), 1993, Archbishop Oscar Romero: A shepherd's diary, CAFOD, London.

Keogh, D., 1981, Romero: El Salvador's martyr - A study of the tragedy of El Salvador, Dominican Publications, Dublin.

KrierMich, M.L., 2001, Catholic social teach and movements, Twenty-Third Publications, New York, NY.

Leaders, 2000, Hopeless Africa, viewed 27 March 2018, from https://www.economist. com/leaders/2000/05/11/hopeless-africa.

McGarry, P., 2018, Oscar Romero: One-time conservative who became a nation's socia martyr, viewed 07 February 2019, from https://www.irishtimes.com/news/socialaffairs/religion-and-beliefs/oscar-romero-one-time-conservative-who-became-anation-s-social-martyr-1.3657423.

Marc-Ela, J., 1986, African cry, Orbis Books, New York, NY.

Marc-Ela, J., 1988, My faith as an African, Orbis Books, New York, NY.

Marc-Ela, J., 1996, 'The church - Sacrament of liberation', in M. Browne (ed.), The African synod: Documents, reflections, perspectives, pp. 131-138, Orbis Books, New York, NY

Morozzodella Rocca, R., 2015, Oscar Romero: Prophet of hope, Darton, Longman and Todd, London.

Nouwen, H.J.M., 1989, 'Foreword', in J.R. Brockman (ed.), Theviolence of love: The words of Oscar Romero, pp. vii-xi, Fount Papers, London.

Romero, O., 1979, Misión de la Iglesia en medio de la crisis del país, viewed 16 March 2019, from https://www.google.com/url?sa=t\&rct=j\&q=\&esrc=s\&source=web\&cd $=2 \&$ cad $=$ rja\&uact $=8 \& v e d=2$ ahUKEwjL2NGr_J7oAhXU8eAKHXeCCWKQFjABegQIAx AB\&url=http\%3A\%2F\%2Fwww.romerotrust.org.uk\%2Fsites $\% 2$ Fdefault $\% 2$ Ffiles $\% 2 \mathrm{~F}$ homilies\%2F1979\%252008\%252006\%2520Mision\%2520de\%2520la\%2520lglesia\% 2520 en $\% 2520$ medio\%2 $2520 \mathrm{de} \% 2520$ la\%2520crisis $\% 2520 \mathrm{del} \% 2520$ pais.pdf\&usg=A
OvVaw1VoOANCk5b3e3hzq6nyXQX.

Rousseau, R.W., 2002, Human dignity and the common good: The great papal social encyclicals from Leo XIII to John Paul II, Greenwood Press, Westport, CT.

Sobrino, J., 1990, Archbishop Romero: Memories and reflections, Orbis Books, New York, NY

Sobrino, J., 2008, No salvation outside the poor: Prophetic-utopian essays, Orbis Books, New York, NY

Wright, S., 2009, Oscar Romero and the communion of saints, Orbis Books, New York, NY. 